\title{
THE EFFECT OF THE TRAINING PROGRAMME ON STUDENTS MOTIVATION FOR RESEARCH ACTIVITY
}

\author{
Natalia V. Kozlova, Inna V. Atamanova \\ Tomsk State University, Tomsk, Russia \\ E-mail: akme_2003@mail.ru, iatamanova@yandex.ru
}

\begin{abstract}
One of the main goals of higher professional education is to provide national communities with highly qualified human resource. In turn, the global challenge of transition to a knowledge-based society influences the national systems of professional training and predetermines a substantial increase in the role of innovations and scientific research in the countries' economic and social progress. Therefore, it is essentially important that the system of professional education be aimed at developing students' research competence in higher educational settings. As shown, the Russian students are mainly aware of the necessity of research work as a part of the educational curriculum and its importance. On the other hand, most of them do not have much interest in their own research projects.

The paper discusses the problem of students'motivation for research activity from the psychological-acmeological point of view. This approach seems to be beneficial since it takes into account the idea of sustainable development and lifelong learning. The study presented was aimed at evaluating the effect of the training programme on students'motivation for research activity which was implemented into the educational process. The results of the programme implementation have shown a significant change in students' motives for doing research among undergraduate students whose majors were natural sciences, mathematics and electrical engineering.
\end{abstract}

Key words: higher professional education, personal and professional development, research activity, researchbased teaching, students'motivation.

\section{Introduction}

The national systems of higher professional education are much affected by the global challenge of transition from resource-oriented economies to knowledge-based ones. As emphasized, "the emerging knowledge economy is one that requires individuals with creativity and ability to develop, find and synthesize new knowledge" (Jenkins et al., 2003, p. 24). In a wider sense, the emerging knowledge-based societies are calling for countries' innovative development.

In Russia the strategy of innovative development is viewed as one of the most important factors of modernizing both the national economy and the society (Стратегия, 2011). It is worth mentioning that innovative development, which is traditionally associated with innovations in technologies, is highly influenced by the human factor (Краснорядцева, 2008; Клочко \& Галажинский, 2009; 
Atamanova \& Bogomaz, 2011). In this connection, it is expected that higher professional education should play a crucial role in providing science and economy with highly qualified specialists (OECD, 2007). It should be noted that the term higher professional education is commonly used in Russia and some other countries to highlight practical orientation of tertiary education. According to the third-generation State Standards for Higher Professional Education adopted in Russia, graduates' competence in project and research activity is determined as one of the main objectives of professional training in higher educational settings (EDU, 2009). On the other hand, the conventional system of higher professional education is not fully adequate to meet the challenge of the $21^{\text {st }}$ century (Агранович et al., 2003; Похолков et al., 2003). In consequence, various ideas and concepts of reforming the scientific and educational complex have been proposed. One of the major directions is the development of science by its popularization and active involvement of young people (students and postgraduates) in scientific research.

Students' research activity seems to be of great importance and can be viewed as a way of transformation from traditional engineering education to innovative one where students are involved in research since the very beginning. Researching enables students to integrate the knowledge they gain and solve efficiently the tasks they deal with (Козлова, 2008). This also helps students develop their readiness for solving various problems they may encounter in their future career (Козлова, 2009; Козлова et al., 2009). As shown in (Козлова \& Луков, 2007), the Russian engineering students were mainly aware of the necessity of research work as a part of their educational curriculum and its importance. However, most of them did not have much interest in their own research projects.

Thus, the study presented addresses the problem of students' motivation for research activity. The psychological-acmeological approach seems to contribute much to our understanding of the phenomenon under study since it takes into account the idea of sustainable development and lifelong learning. This study was aimed at evaluating the effect of the training programme created for developing students' motivation for research activity and implemented into the educational process.

\section{Calls for Studies on Students Motivation for Research}

Having summarized researchers' findings on how students learn, Wood (2009) concludes that research-based teaching methods seem to be more effective in training students, for instance, in science, technology, engineering or mathematics. It should be noted that these methods are based on the philosophy of active learning. Meanwhile, they reflect, according to Wood, the idea of integration of university "research and teaching missions" and aim at "involving more students in the process of research" (p. 107). He compares traditional practices with research-based ones for nine course aspects, namely content organization, student organization, feedback, in-class learning activities, out-of-class learning activities, student-faculty interaction in class, student-faculty interaction out of class, use of teaching assistants and student laboratories. The result of comparison is his call for transformation not in "what we teach our students" but in "how we teach them" (p. 108).

Moreover, Wood emphasizes that this idea is not a novelty. It was paid attention to as early as in the 1960s. Having highlighted "the shortcomings of passive learning environments for learners of all ages", Holt $(1964,1967)$ and Kozol (1967) called for "optimal conditions for meaningful learning" (see Wood, 2009, p. 95). It should be noted that the concept of meaningful learning, being active learning by its very nature, has much in common with basic ideas of Lev Vygotsky's socio-cultural theory conceived of in the early 1930s and Alexey Leontiev's activity theory which he began to develop in 1930s. According to Vygotsky (Выготский, 2002, the original was written in 1931), human mind and, therefore, human behaviour are socially and culturally mediated and developed through human activity. In turn, Leontiev (Леонтьев, 1977) showed that human activity is motivated either by biological needs or by culturally constructed needs and includes three levels, namely motivation, action and conditions. Thus, motivation plays an important role in human development as a whole and, therefore, in personal and professional development.

Studies on motivation differ greatly in their scope and researchers' emphases. As for student learning, motivation is the term that characterizes "those inner processes that determine whether learners will engage in a task, the amount of effort they will expand, the length of time they will persevere and the persistence they will show when obstacles are encountered" (Jenkins et al., 2003, 
p. 32). Having initiated in 1995 a series of studies on how lecturer research affects student learning, Jenkins and coworkers (2003) revealed that it was positively valued by the students and perceived as beneficial to their learning. The researchers note that "both undergraduate and postgraduates think that research activity makes their lecturers more enthusiastic, increase their credibility and ensures that their knowledge is up to date" (p. 33). Moreover, postgraduates "expect the lecturers who support their learning to be involved in research" (ibid.). On the other hand, their findings showed that students' attitudes towards research in their departments were much affected by students' goals. In fact, positive attitudes correlated with students' orientation towards "acquiring theoretical knowledge for the purpose of 'developing one's potential', attaining 'freedom at work', becoming involved in 'interesting' and 'creative work', 'influencing society' and 'achieving important things' in professional practice" (Jenkins et al., 2003, p. 34).

Jenkins et al. (2003) also focus on the relationship between motivation and learning. In their opinion, there are three most important aspects: 1) learning requires effort and learners expect to be compensated by some benefits for their efforts; 2 ) learning is usually motivated by a desire for improvement in something; 3 ) some motives such as fear of failure or anxiety to succeed usually disable learning. Based on the above, the researchers formulate three general principles of managing student learning, namely "make learning rewarding", "discover learners' goals" and "minimize obstacles to learning" (p. 37-38). In other words, it is motivation that can contribute much to educational practice in order to enhance the development of students' competence in research.

According to O'Leary (2004), research can be viewed as a journey and, therefore, "it needs to be managed, navigated, and negotiated from early conceptions to final destination" (p. 15). From this perspective researching is a skill to be developed or, in O'Leary's words, "a learning journey about both research itself and your ability to manage intricacies and complexity" (ibid.). Jenkins et al. (2003) seem to share the idea above when emphasizing that "students' understanding of the research process and ability to do research (...) may be the vital key skill or knowledge the curriculum needs to develop" (p. 24). Thus, taking into account that research activity is not only a part of educational process but also enhances students' personal and professional development, it is necessary to introduce such forms of educational practice that enable to motivate students and improve their research work qualitatively as well as professional education as a whole.

\section{Psychological-acmeological Approach}

The current system of higher professional education in Russia has encountered some problems connected with innovative changes and their practical implementation. In spite of the variety of methodological approaches to examining current trends in education and the possibilities of their realization, it is required to revise the theoretical and methodological principles of the system of education in general and higher professional education in particular. The reason is that the socio-cultural and psychological meaning of professional activity often remains hidden to a future specialist. Accomplishing such complicated goals of education is possible by means of acmeology which purposefully focuses on professionalism and factors affecting it as its research subject and provides a theoretical and methodological background for modelling, developing and enhancing systems of professional training (Деркач et al., 2000; O’Meara et al., 2001; Conley \& Leslie, 2002; Козлова, 2005). Close interrelation of acmeology, first of all, with pedagogical and psychological studies makes it urgent to introduce new systems of knowledge into practice of higher professional education by appealing to the conditions and factors identified and analyzed at different stages of personal and professional development. They are viewed through the lens of professionalism and professional mastery and among them an essential role belongs to the orientation towards scientific research.

The word acme has its origin from the Greek word $\alpha \kappa \mu \eta$ that means the highest point of something, peak, mature age or full bloom of life (Козлова \& Берестнева, 2006). Acme can be viewed as the highest stage of development or the most excellent example of something. Thus, personal and professional development can be referred to as one's lifelong journey to acme.

Nothing can contribute to the development of a future specialist as much as a self-conducted research project. Successfully conducted research stimulates cognitive activity and helps students gain self-confidence. Research activity enables students to discover their scientific potential and cre- 
ativity (Разумовский, 2004). Students' research work is of great significance for the entire structure of their professional training for several reasons: it enables students to gain additional information and knowledge in the newest areas of fundamental and applied research, equips them with various research techniques, allows to comprehend the current socio-economic phenomena and processes fully and systematically and trains them to formulate and solve scientific problems on their own and to present their findings at seminars and conferences. Therefore, the psychological-acmeological perspective enables us to view students' research work as one of the essential ways of developing their competence in a professional field and as one of the key factors of students' personal and professional development in higher educational settings.

\section{Training Programme Students Research Work}

The analysis of theoretical and methodological foundations and educational practices led us to develop and implement into practice a training programme called Students Research Work (Козлова \& Луков, 2007), which has been realized in the groups of undergraduate and master students of Tomsk Polytechnic University and Tomsk State University. The training cycle lasts for two semesters, the main purpose being the development of research competence through involving students in research activity.

The key goals of this complex of training sessions are: 1) increasing students' activity by developing their personal and professional qualities - leadership, communication, creativity; 2) training students in various techniques of scientific research - brainstorming, project management, system analysis, basics of presentation skills; 3 ) developing students' motivation for research activity by means of management and business games, motivational trainings and meetings with junior and senior researchers.

According to (Луков, 2005), the training sessions are divided into three stages depending on the objectives as follows. First, Development of Students' Activity is aimed at developing ideas about personal and professional qualities which contribute to progressive and steady development. Second, Training in Techniques of Scientific Research serves to familiarize students with heuristic techniques, basics of presentation skills, algorithms of inventive problem solving, project management. Third, Developing Motivation for Research Activity is the final and most important part of this complex which is aimed at testing scientific ideas and evaluating the possibility of promoting created scientific products.

For the purpose of student assessment, specific criteria for the tutors implementing this programme were developed:

1. Students' activity is assessed at each session. To do this, during the session the tutor takes into account various types of activity of each student over a short period of time. These types may include leadership, communication, creative and cognitive activities. At the end of the session the tutor makes an expert assessment of activity of each student. Thus, we can not only trace the dynamics of students' activity but also determine their activity on different aspects of the training sessions.

2. Interest in science. This criterion reflects students' attendance of various scientific events (meetings of the departments' methodological boards, conferences, seminars, etc.) and their participation in research projects being carried out in their departments.

3. Results of scientific activity. This criterion is determined as a specific "product" of students' scientific activity, e.g. their presentations at conferences and seminars, various publications, participation in scientific competitions, etc.

4. Feedback. This criterion is based on the students' opinions on the impact of the complex of training sessions on their motivation, activity and engagement in scientific research. To elicit feedback, we asked the students to write a short essay about their scientific achievements and their views on the role of the training sessions, including their pros and cons, as well. 


\section{Research Methodology}

Based on the theoretical analysis given above and the training programme described the study was conducted as follows. It should be mentioned that it was one in a series of the long-term research project dealing with the problem of students' motivation for research activity. The goal of the study presented was to examine the effect of the programme implemented into educational practice, Students Research Work, on students' motivation for research activity.

\section{Sample}

The study sample consisted of 160 university undergraduates between the ages of nineteen and twenty-one. All of them were students of Tomsk Polytechnic University and the training course, Students Research Work, was a part of their educational curriculum in the 2010/2011 academic year. Their majors were natural sciences (26 students), mathematics (48 students) and electrical engineering ( 86 students). The gender issue was not taken into account because it was not a research question in this study.

\section{Data Collection}

Based on the Students' Motives for Studying Questionnaire developed by A. Rean and V. Yakunin (see Ильин, 2002), the following 10 motives were chosen as students' motives for doing research in order to evaluate the effect of the training programme on students' motivation for research activity.

Motive 1-to ensure their future professional success. Motive 2 - to become a highly qualified specialist and get a diploma. Motive 3 - to acquire deep and sound knowledge. Motive 4 - to get intellectual satisfaction. Motive 5 - to study successfully and get excellent and good marks in exams. Motive 6 - to be successful in further studying and get a regular grant. Motive 7 - to be respected by tutors and approved by parents and other people. Motive 8 - to follow tutors' requirements and be an example to peers. Motive 9 - not to neglect academic subjects. Motive 10 - to be always ready for the next class and keep up with peers.

The participants were asked to choose their five dominant motives for doing research from the list mentioned above (the text was in Russian) at the beginning and at the end of the training course.

\section{Data Analysis}

The data analysis involved a quantitative and a qualitative dimension. The distribution, hierarchy and characteristics of the students' dominant motives for doing research at the beginning and at the end of the training programme were analyzed and compared.

\section{Results of Research}

The results obtained at the beginning of the training course can be seen in Table 1 and Figure 1. Table 1 presents the hierarchy of students' dominant motives for doing research and Figure 1 illustrates their distribution at the beginning of the training programme. Motives from 1 to 10 are listed as defined in Section Data collection. 


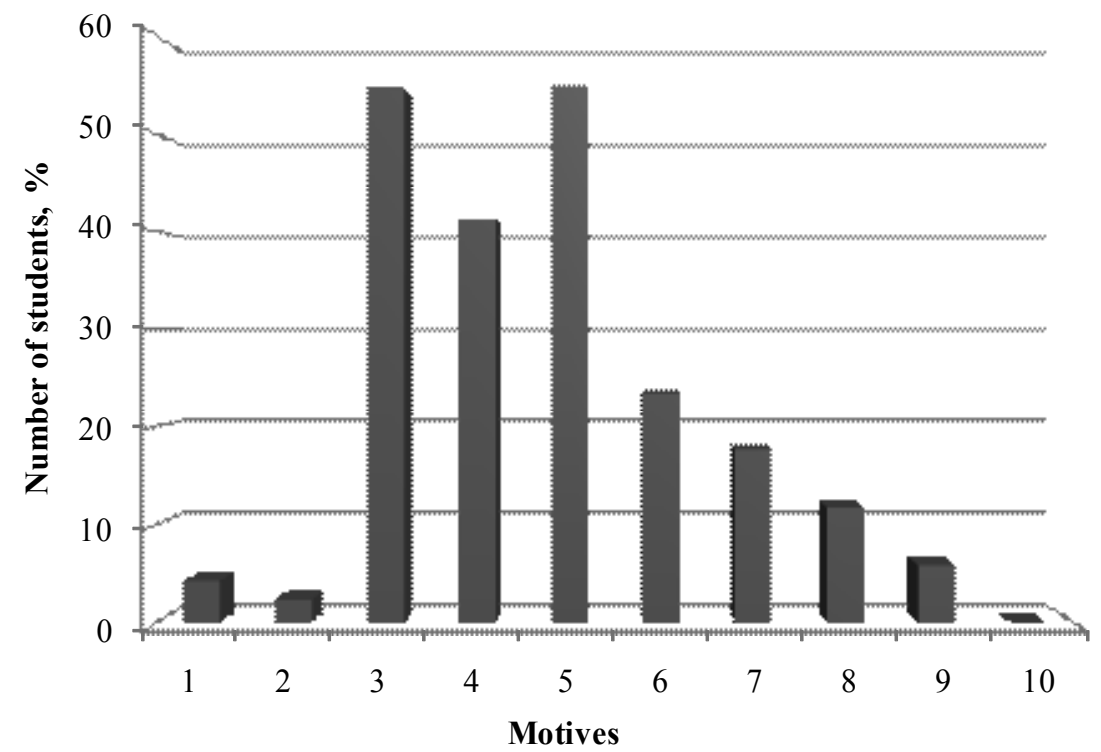

Figure 1: The distribution of students' motives for doing research before implementation of the training programme.

Table 1. The hierarchy of students' motives for doing research before and after implementation of the training programme.

\begin{tabular}{|c|c|c|c|}
\hline \multicolumn{2}{|l|}{ Before implementation } & \multicolumn{2}{|l|}{ After implementation } \\
\hline Motives & $\begin{array}{l}\text { Students, } \\
\%\end{array}$ & Motives & $\begin{array}{c}\text { Students, } \\
\%\end{array}$ \\
\hline $\begin{array}{l}\text { To study successfully and get excellent } \\
\text { and good marks in exams }\end{array}$ & 54.94 & $\begin{array}{l}\text { To ensure their future professional } \\
\text { success }\end{array}$ & 100 \\
\hline To acquire deep and sound knowledge & 54.7 & $\begin{array}{l}\text { To become a highly qualified specialist } \\
\text { and get a diploma }\end{array}$ & 82.35 \\
\hline To get intellectual satisfaction & 41.2 & To acquire deep and sound knowledge & 64.7 \\
\hline $\begin{array}{l}\text { To be successful in further studying and } \\
\text { get a regular grant }\end{array}$ & 23.53 & To get intellectual satisfaction & 24.94 \\
\hline $\begin{array}{l}\text { To be respected by tutors and approved } \\
\text { by parents and other people }\end{array}$ & 17.65 & $\begin{array}{l}\text { To study successfully and get excellent } \\
\text { and good marks in exams }\end{array}$ & 11.2 \\
\hline $\begin{array}{l}\text { To follow tutors' requirements and be an } \\
\text { example to peers }\end{array}$ & 11.77 & $\begin{array}{l}\text { To be successful in further studying and } \\
\text { get a regular grant }\end{array}$ & 3.53 \\
\hline Not to neglect academic subjects & 5.9 & $\begin{array}{l}\text { To be respected by tutors and approved } \\
\text { by parents and other people }\end{array}$ & 0.65 \\
\hline $\begin{array}{l}\text { To ensure their future professional } \\
\text { success }\end{array}$ & 4.3 & $\begin{array}{l}\text { To follow tutors' requirements and be an } \\
\text { example to peers }\end{array}$ & 0.17 \\
\hline $\begin{array}{l}\text { To become a highly qualified specialist } \\
\text { and get a diploma }\end{array}$ & 2.35 & Not to neglect academic subjects & 0 \\
\hline $\begin{array}{l}\text { To be always ready for the next class and } \\
\text { keep up with peers }\end{array}$ & 0 & $\begin{array}{l}\text { To be always ready for the next class } \\
\text { and keep up with peers }\end{array}$ & 0 \\
\hline
\end{tabular}

The results showed that the level of students' awareness of importance of their research work for providing success in their future professional activity was rather low. Very few students determined 'to ensure their future professional success' and 'to become a highly qualified specialist and get a 
diploma' as their dominant motives for doing research, $4.3 \%$ and $2.35 \%$ respectively. Moreover, quite a large number of the students were oriented towards external factors in doing their research projects, namely tutors or other people's respect (17.65\%) and tutors requirements (11.77\%). The most dominant motive for doing research was that of formal academic achievements - 'to study successfully and get excellent and good marks in exams' $-54.94 \%$.

The results obtained at the end of the training programme can be seen in Table 1 and Figure 2. Figure 2 illustrates the distribution of students' dominant motives for doing research at the end of the training course. Motives from 1 to 10 are listed as defined in Section Data collection. Table 1 shows the hierarchy of the students' dominant motives.

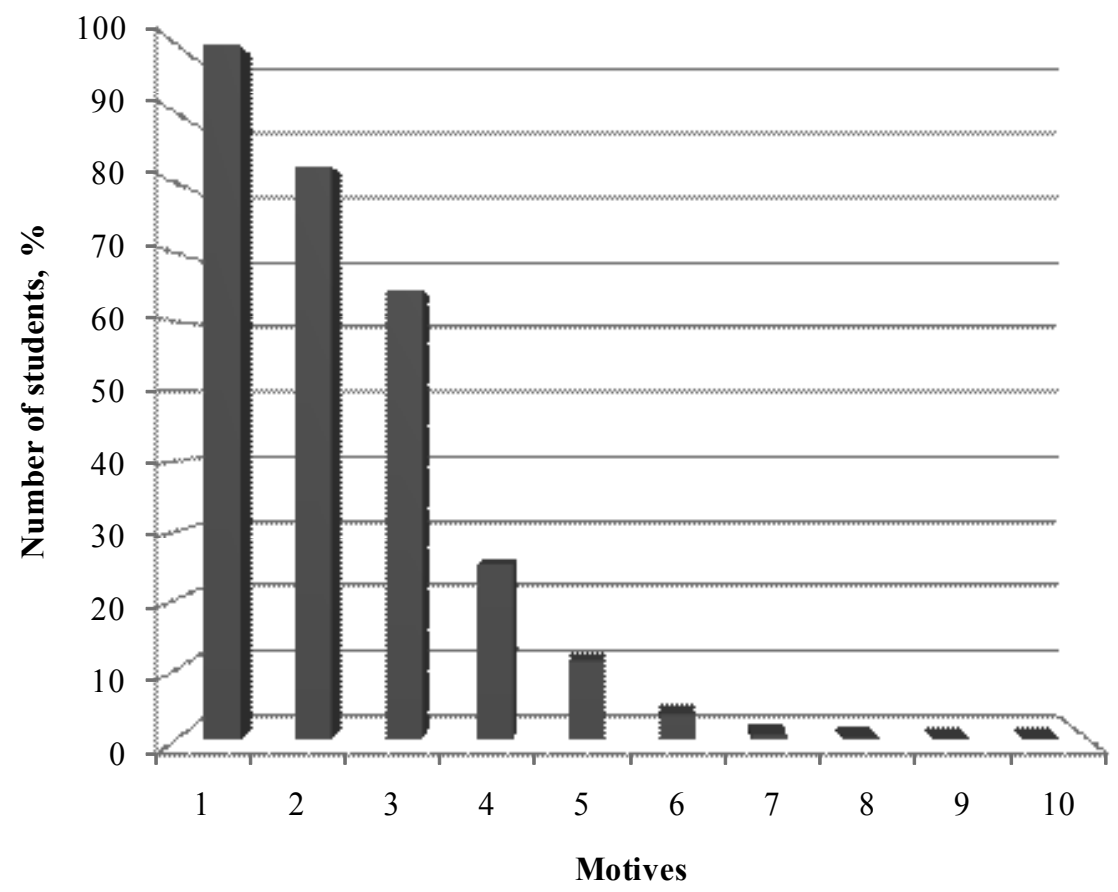

Figure 2: The distribution of students' motives for doing research after implementation of the training programme.

Accordingly, one can observe significant changes in the students' dominant motives for doing research at the end of the training programme. In fact, the participants became more aware of how their research work could contribute to their professional development. Motives 'to ensure their future professional success' and 'to become a highly qualified specialist and get a diploma' were chosen by $100 \%$ and $82.35 \%$ of the students respectively. In other words, there was a significant increase (versus $4.3 \%$ and $2.35 \%$ at the beginning of the training programme) in a number of students who viewed their research work as a base of their successful future career and as an essential condition of high level of competence in a professional field. Moreover, there was a marked decrease in a number of students who were oriented towards external factors or formal academic achievements. Only $0.65 \%$ of the students were oriented towards tutors or other people's respect and only $0.17 \%$ of them chose tutors requirements as a dominant motive for doing research. There was also a large decrease in a number of students motivated by formal academic achievements. 'To study successfully and get excellent and good marks in exams' was chosen by $11.2 \%$ of the participants versus $54.94 \%$ at the beginning of the training course.

Figure 3 illustrates the dynamics of changes in the participants' dominant motives for doing research as a result of implementation of the training programme Students Research Work. Motives from 1 to 10 are listed as defined in Section Data collection. 


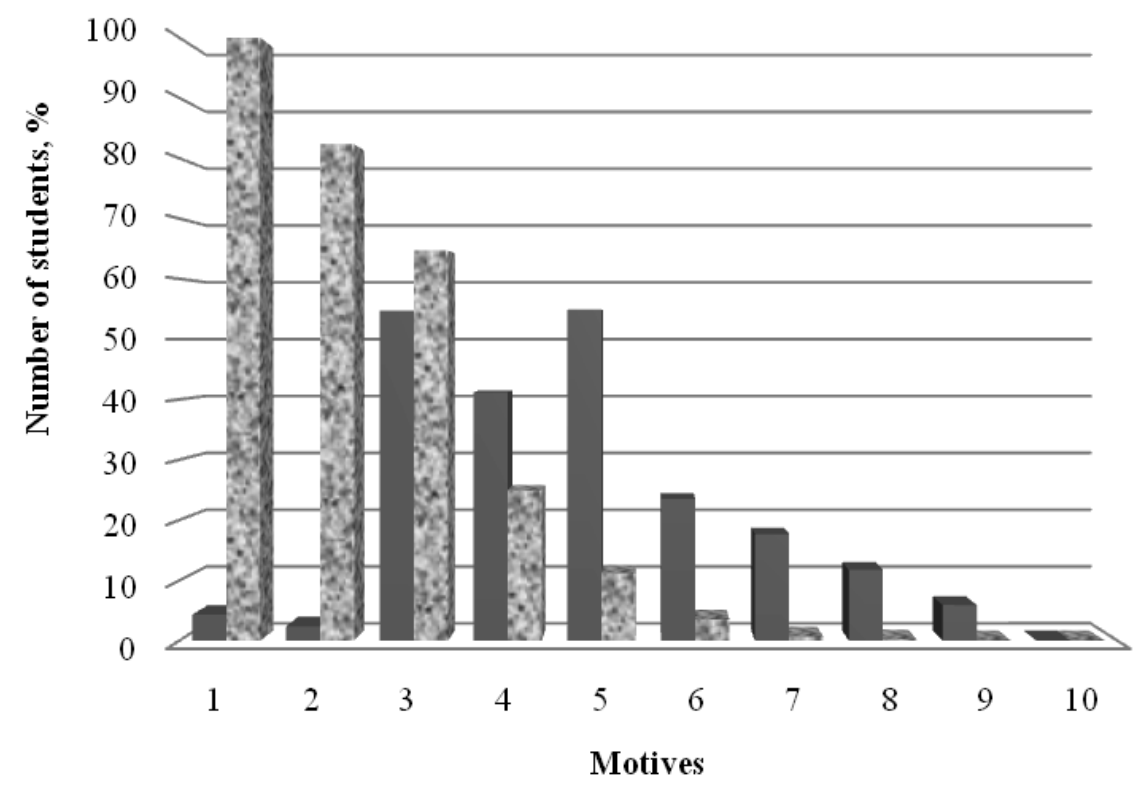

- Before implementation $\quad$ After implementation

Figure 3: The dynamics of changes in students' motives for doing research after implementation of the training programme.

\section{Discussion}

The discussion about the results of the study can be divided into two parts. One concern students' motives for doing research at the beginning of the training programme Students Research Work, the other deals with changes in students' motives for doing research as a result of implementation of this programme.

First of all, the results obtained demonstrate that at the beginning of the training programme most of the participants were not aware of the role of research work in their professional development. They did not understand how their research work could contribute to their future success in a professional field. Most of the students were oriented towards external factors such as tutors or other people's respect and tutors requirements and towards formal academic achievements, namely good marks and success in exams. In other words, the level of students' awareness of importance of their research work for providing success in their future professional activity was rather low.

It should be noted that these results are in good agreement with those of studying research potential of higher professional education (see, e.g., Галиуллина, 2003; Козлова \& Луков, 2007). The researchers point out a low level of students' awareness of the importance of their research work for future professional activity, a decrease in the quality of students' research work, a small number of research projects implemented into practice, a low level of student autonomy in selecting both research topics and trajectories of research. Therefore, the current system of higher professional education requires educational practices enabling students to discover the hidden meaning of professional activity and develop their competence in research.

The main goal of the training programme Students Research Work, which was created and implemented into educational practice, is to develop students' research competence and motivation through involving them in research activity. In other researchers' opinion, the integration of training and students' research work is likely to create real prerequisites for improving the quality of future graduates (Jenkins et al., 2003). Such integration is based on the problem-oriented approach which enables to focus students' attention on the analysis and solution of specific problem situations, and it is not so important to solve the problem (research is an open-ended process) as to competently formulate it (O'Leary, 2004). A problem situation maximally motivates students to gain the very knowledge needed for its solution consciously or, in other words, students' competence in research 
is being developed via meaningful learning (Wood, 2009). Problem-based training is a pedagogical strategy and a special way of acquiring knowledge which makes it possible to fully comprehend a problem through an active, deep and firm insight into real life situations. The role of the tutor is that of a coordinator who guides the students to solve this or that problem and assists them in finding the most efficient and effective way of solving by an active discussion about the difficulties they encounter when working on the problem formulated. Thus, students' research work can be considered an essential factor of training future specialists and scientists, which contributes to the development of their autonomy in reasoning and their ability to concentrate, to constantly enrich their knowledge, to have a multifaceted view of the problems faced and to work purposefully and thoughtfully. Moreover, from the psychological-acmeological perspective, according to Kozlova and others, students' research work can be viewed as one of the most important ways of developing their competence in a professional field and as one of the key factors of students' personal and professional development in higher educational settings (Козлова, 2005; Козлова \& Берестнева, 2006).

The results obtained at the end of the training programme clearly show significant changes in the students' dominant motives for doing research. Actually, the participants became more aware of how their research work could contribute to their professional development. There was a significant increase in a number of students who viewed their research work as a base of their successful future career and as an essential condition of high level of competence in a professional field. Moreover, there was a marked decrease in a number of students who were oriented towards external factors (tutors or other people's respect and tutors requirements) or formal academic achievements (good marks and success in exams).

\section{Conclusion}

The emerging knowledge-based society is calling for countries' innovative development throughout the world. One of the key factors of its transformation in Russia is modernization of the system of higher professional education in order to provide science and economy with highly qualified specialists. Graduates' competence in project and research activity is considered as one of the main objectives of professional training in higher educational settings. Researching enables students to integrate the knowledge they gain, solve efficiently the tasks they deal with, and develop their readiness for solving various problems in their future career. However, a number of studies showed that despite their awareness of the necessity of research work as a part of their educational curriculum and its importance, most of the students did not have much interest in their own research projects.

Theoretical analysis of a number of publications on the problem of students' motivation, students' research and learning discovered the necessity of exploring possible ways of transforming current educational practices into research-based ones. On the other hand, motivation is considered to play an important role in personal and professional development. It was suggested that the psychologicalacmeological approach focused on one's lifelong journey to acme, the highest stage of development, could contribute much to the development of students' competence in research via developing their motivation for research activity.

The study presented was aimed at evaluating the effect of the training programme Students Research Work on students' motivation for research activity. This programme was created and implemented into educational practice, its main goal being the development of students' research competence and motivation through involving them in the process of research.

The results obtained showed a significant increase in a number of students who viewed their research work as a key factor of their professional development at the end of the course. On the other hand, there was a marked decrease in students' orientations towards external factors or formal academic achievements. In other words, the results obtained indicated some positive dynamics of changes in the participants' motives for doing research in higher educational settings.

Thus, it should be concluded that the training programme based on the psychological-acmeological approach to students' personal and professional development can be a useful tool of developing both students' research competence and their motivation for doing research. 


\section{References}

Atamanova, I., \& Bogomaz, S. (2011). Language Learning through Content: What can help university students develop their communicative competence in a professional field? In B. Swaffield \& I. Guske (Eds.): Global Encounters: Pedagogical Paradigms and Educational Practices (pp. 93-105). Cambridge, UK: Cambridge Scholars Publishing.

Conley, V. M., \& Leslie, D. W. (2002). Executive Summary of the Statistical Analysis Report (Summer 2002). U. S. Department of Education, National Center for Education Statistics. Washington, USA.

EDU. (2009). Федеральные государственные образовательные стандарты высшего профессионального образования. Retrieved 26/10/2010, from http://www.edu.ru/db/ portal/spe/archiv_new.htm

Holt, J. (1964). How Children Fail. New York, USA: Pitman.

Holt, J. (1967). How Children Learn. New York, USA: Pitman.

Jenkins, A., Breen, R., Lindsay, R. \& Brew, A. (2003). Reshaping Teaching in Higher Education: Linking Teaching with Research. Abington, UK: Routledge Limited.

Kozol, J. (1967). Death at an Early Age. Boston, USA: Houghton-Mifflin.

OECD. (2007). Country Background Report for the Russian Federation. OECD Thematic Review of Tertiary Education. Retrieved 29/10/2010 from http:/www.oecd.org/ dataoecd/22/10/40111027.pdf

O'Leary, Z. (2004). The Essential Guide to Doing Research. London, UK: SAGE Publications Ltd.

O’Meara, P., Mehlinger, H., \& Newman, R. (Eds.) (2001). Changing Perspectives in International Education. Bloomington, USA: Indiana University Press.

Wood, W. (2009). Innovations in Teaching Undergraduate Biology and Why We Need Them. Annual Review of Cell and Developmental Biology, 25, 93-112.

Агранович, Б. Л., Чучалин, А. И., \& Соловьев, М. А. (2003). Инженерное инновационное образование. Инженерное образование, 1, 11-14.

Выготский, Л. С. (2002). История развития высших психических функций. In Л.С. Выготский: Психология (рр. 512-755). Москва, Россия: Издательство ЭКСМО-Пресс.

Галиуллина, Ф. Ш. (2003). [Electronic Version]. К проблеме совершенствования готовности студентов ВУЗов к научно-исследовательской деятельности. Вестник ТИСБИ, 3. Retrieved 14/09/2009 from http://old.tisbi.org/science/vestnik/2003/ issue3/econom1.html

Деркач, А. А., Зазыкин, В. Г., \& Маркова, А. К. (2000). Психология развития профессионала. Москва, Россия: РАГС.

Ильин, Е. П. (2002). Мотиваџия и мотивы. Санкт-Петербург, Россия: Питер.

Козлова, Н. В. (2005). Психолого-акмеологический потенциал в обучении студентов высшей школы. Образование в Сибири, 13, 31-36.

Козлова, Н. В., \& Берестнева, О. Г. (2006). Высшая техническая школа и инженерное образование в современных условиях (психолого-акмеологический подход). Известия Томского политехнического университета, 2 (309), 229-234.

Козлова, Н. В., \& Луков, Д. В. (2007). Комплексная программа повышения мотивации к научной деятельности (психолого-акмеологический подход). Известия Томского политехнического университета,3 (309), 211-217.

Козлова, Н. В. (2008). [Electronic Version]. Личностно-профессиональное становление в условиях вузовского образования: акме-ориентированный подход. Автореферат диссертации на соискание ученой степени доктора психологических наук: 19.00.13. Томск, Россия. Retrieved 14/10/2011 from http://sun.tsu.ru/mminfo/ 000338260/000338260.pdf

Козлова, Н. В. (2009). Мотивационные факторы формирования кадрового резерва в инновационном образовательном процессе. Вестник Томского государственного университета, 318, 199-203.

Козлова, Н. В., Берестнева, О. Г., \& Шелехов, И. Л. (2009). Особенности личностного и профессионального становления студентов университета. Вестник Томского государственного педагогического университета, 9, 103-107.

Клочко, В. Е., \& Галажинский, Э. В. (2009). Исследование инновационного потенциала личности: концептуальные основания. Сибирский психологический журнал, 33, 6-12. 
52 Краснорядцева, О. М. (2008). Психолого-образовательное сопровождение процесса вхождения молодежи в инновационную деятельность. Психология и современное российское образование: Материаль IV Всероссийского съезда психологов образования (рр. 10-19). Москва, Россия.

Леонтьев, А. Н. (1977). Деятельность. Сознание. Личность. Москва, Россия: Политиздат.

Луков, Д. В. (2005). Развитие профессиональной компетенции студентов экономических специальностей в Томском политехническом университете. Молодые учёные - промышиленности, науке, технологиям и профессиональному образованию: проблемы и новые решения: Сборник научных докладов международной конферениии (рp. 489-491). Москва, Россия: МГИУ.

Похолков, Ю. П., Вайсбурд, Д. И., \& Чубик, П. С. (2003). Элитное образование в традиционном техническом университете. Элитное техническое образование: Труды международной конференции в рамках симпозиума,1 (рр. 6-8). Томск, Россия: Издательство ТПУ.

Разумовский, В. Г. (2004). Научный метод познания и личностная ориентация образования. Педагогика, $6,24-26$.

Стратегия (2011). [Electronic Version]. Стратегия инноваџионного развития Российской Федеращии на период до 2020 года. Retrieved 20/12/2011 from http:/government.ru/media/2011/12/21/46988/ file/2227-pril.doc

Advised by Sergey A. Bogomaz, Tomsk State University, Russia

Received: May 07, 2012

Accepted: June 19, 2012

Natalia V. Kozlova PhD., Professor, Department of Psychology, Tomsk State University, Tomsk, Apt. 126, 6 Nekrasov Street, Russia.

Phone: +79069483401 .

E-mail: akme_2003@mail.ru

Website: http://www.tsu.ru/english/ 